\title{
Future workshops as a means to democratic, inclusive and empowering research with children, young people and others
}

\author{
Alminde, Sarah; Warming, Hanne \\ Published in: \\ Qualitative Research
}

DOI:

10.1177/1468794119863165

Publication date:

2020

Document Version

Peer reviewed version

Citation for published version (APA):

Alminde, S., \& Warming, H. (2020). Future workshops as a means to democratic, inclusive and empowering research with children, young people and others. Qualitative Research, 20(4), 432-448.

https://doi.org/10.1177/1468794119863165

\section{General rights}

Copyright and moral rights for the publications made accessible in the public portal are retained by the authors and/or other copyright owners and it is a condition of accessing publications that users recognise and abide by the legal requirements associated with these rights.

- Users may download and print one copy of any publication from the public portal for the purpose of private study or research.

- You may not further distribute the material or use it for any profit-making activity or commercial gain.

- You may freely distribute the URL identifying the publication in the public portal.

\section{Take down policy}

If you believe that this document breaches copyright please contact rucforsk@kb.dk providing details, and we will remove access to the work immediately and investigate your claim. 


\title{
Future workshops as a means to democratic, inclusive and empowering research with children, young people and other
}

\begin{abstract}
During the past decade, awareness has grown concerning the need for more democratic and inclusive research methods. This is especially salient for marginalised, colonised and silenced groups, such as the elderly, children and young people. In this article, we present and discuss future workshops as an appropriate method to achieve such democratic and inclusive research, and we posit that it can fruitfully be used together with other approaches outside the field of action research in which it has mostly been used to date. The discussion is based on our research with children and young people on sensitive and conflictual issues. We show how future workshops offer particular advantages when conducting research with children and young people in vulnerable situations, and about silenced and sensitive topics. We argue that these advantages, as well as ethical and other insights, can be transferred to research with other groups of people. (135 words)
\end{abstract}

Keywords: Future workshop, democratic research, participatory methodologies, divorce, childhood, children and youth in research, silenced groups, research methods, qualitative research

\section{Introduction}

During the past decades, voices that radically challenge traditional research practices and advocate more democratic and participatory methodological approaches have grown louder, as pointed out in the introduction to a recent special issue of this journal by Edwards and Brannelly (2017). This appears to be a broad tendency; however, it is especially relevant when it comes to marginalised, colonised or 'silenced' groups' (see Chilisa, 2012; Hitchcock and Wesner, 2011; Nind, 2017) such as the elderly (Andersen and Bilfeldt, 2015), children, and young people (Alderson, 2000; Lyon and Carabelli, 2015; Åkerström and Brunnberg, 2012). The arguments for challenging conventional methodological approaches are ethical as well as political. Following Emmanuel Levinas' (1969) philosophy of ethics, which argues that reducing the other to a historically-created or psychologically comprehensible individual is violence against him or her, it becomes a basic ethical requirement to always meet the other with openness to his or her particularities and otherness. From a political democratic perspective, every individual should have the right to influence the processes and communities in which they participate, including research projects. 
This has become so much more pertinent in the light of the Foucauldian recognition of the intertwined nature of power and knowledge (Foucault, 1981). Thus, democratising knowledge production and rethinking our methodological approaches for this purpose have been identified as the key methodological challenges of the 21st century (Crow, 2012; Edwards and Brannelly, 2017). In this article, we present and discuss future workshops as a means to achieving democratic and inclusive research, based on our research with children and young people on sensitive and conflictual issues.

\section{Future workshops in research with children and young people}

Future workshops were originally developed as an action research method with adults in mind (see Jungk and Müllert, 1987; Nielsen, 1992). However, Christensen and James (2000) argue that carrying out research with children does not necessarily require a unique method, since there is nothing particular or peculiar about children that calls for this. Thus, it has been widely established that children can and do participate in interviews, questionnaires, observational studies, action research, etc. Nonetheless, it is our experience that doing research with children does sometimes pose 'ordinary' methodological and ethical challenges in new ways or make them more visible than in research with adults, thereby making research with children what Flyvbjerg (2006) has termed an extreme or exemplary learning case. As argued by Samantha Punch, doing research with children is the same, but different 'mainly due to adults' perceptions of children and children's marginalised position in adult society' (Punch, 2002: 321). Still, the characteristics of the children that participate in the research, the topic the research aims to investigate, and the social and cultural context of the research project, are far more important when choosing a suitable research method than the fact that the research subjects are not adults (Christensen and James, 2000:2). In line with this, future workshops, despite being developed with adults in mind, can and have been used in research both with adults and children, and insights and reflections on experiences from future workshops with children are relevant in other fields of research as well.

In addition to these ethical and democratic rationales, the new social studies of childhood (which is no longer that new) distinguishes itself from conventional research paradigms by approaching childhood as a social phenomenon rather than just a life phase (Christensen and James, 2000; Corsaro, 2005; James, Jenks and Prout, 1998; Qvortrup, 1994). Scholars in this field have, in addition, offered epistemological rationales for adopting participatory approaches. The new social studies of childhood is critical of the tendency in traditional developmental psychology to view children as passive objects of adult agency (education, socialisation, etc.), and to take children's under-privileged power position in the social order as natural (Cosaro, 2005; James et al., 1998; Wall 2013 and 2014; Author, 2018) Thus, the relational nature of childhood and the structured agency and interdependency of children as well as adults are emphasised (Raiteilhuber, 2016; Wihstutz, 2017). Subsequently, and in line with Dewey's pragmatism (1907), a growing 
body of literature has pointed out the need to take into account children's own experiences, rationales, and special knowledge about what it means to be a child in order to produce valid knowledge about the ongoing, negotiated (re)construction of the social phenomenon called 'childhood' (Brusselius-Jensen, 2014; Clark and Moss, 2011; Grower, 2004; Hallet and Prout eds, 2003; Mayall, 2000; Author, 2011).

These ethical, democratic and epistemological rationales have led to a wide range of participatory research designs as well as ongoing discussions about the possibilities and challenges of exploring and representing children's perspectives (Clark, 2011; Dockett and Bottrell, 2015; Groundwater-Smith et al. 2015; Uprichard, 2010; Author, 2011, 2016). As part of this, several Danish researchers specialising in children and youth, as well as the National Council for Children in Denmark, have turned to future workshops as a possible route to a more inclusive and democratic methodology for exploring children and young people's perspectives and for involving them in changes to practice. These scholars include Brusselius-Jensen (2010), who used the method to investigate how the provision of school meals, particularly the dining environment, should be designed in order to appeal to pupils; Fjordside (2010), who conducted future workshops with young people in Greenland; Clausen and Schmidt (2017), who explored children's perspectives on health in their school life; Bladt (2013) and Brennalt et al. (2017), who investigated marginalised young people's perspectives; Rasmussen (2014) and Holmstrøm et al. (2011), who used the method to create empowerment and changes in the everyday lives of children in daycare and minority girls, respectively; and Author et al. (Author, 2016; Author et al. 2017), who used a future workshop-inspired method called 'up-side-down workshops' to challenge and change the stigmatising labelling of children and young people in vulnerable situations.

The above-mentioned child and youth researchers who have used the future workshop method all also draw on a broader Scandinavian action research tradition called critical utopian action research, in which critique and utopia are core activities in their methodological design (Bladt and Aagaard Nielsen, 2013, see also Andersen and Bilfeldt, 2015; Henning, Åhnby and Österström, 2009). The rationale for working with critique and utopia derives from this research tradition's connection to critical theory, and a 'commitment to democratic social changes' (Andersen and Bilfeldt, 2015: 19; Bladt and Aagaard Nielsen, 2013). The National Council for Children in Denmark, which has also used these methods with various groups of children and young people, argues that future workshops are not only a valuable method that enhances children's and young people's engaged participation but also, through collective learning in a playful space, empowers them in regard to reflecting and acting upon their life conditions and formulating their views (Børnerådet 2016). Similar conclusions are drawn by Brennalt et al. (2017); Holmstrøm et al. (2011); Fjordside et al. (2016) and Author (2016). 


\section{Future workshops in the international research literature}

Despite an overwhelming amount of international publications on children and young people's participation in research - i.e. on doing research with children and young people rather than on them (e.g. Clark and Moss, 2011; Groundwater-Smith et al., 2015; Lyon and Carabelli, 2015; PercySmith and Thomas eds, 2010, to mention but a few) and a growing, broader interest in democratic and inclusive research approaches (see e.g. the special issue in this journal edited by Edwards and Brandnelly, 2017) as well as, in the Danish context, the widespread use and recognition of future workshops as a valuable methodological tool enhancing democratic and inclusive research with children, young people and other marginalised groups, the approach has rarely been thoroughly described and discussed in the international literature on qualitative research. When it is addressed, the focus is on the challenges of creating a space for utopian thinking (Bladt and Aagaard, 2013), the creation of future images as a tool for collective action (Andersen \& Bilfeldt, 2015; Bladt and Aagaard, 2013; Bodinet, 2016; Henning et al., 2009; Hitchcock and Wesner, 2011) or, as argued by Petersen (2006: 616), 'to establish inter-organisational arenas of learning and initiate dialogue across functional barriers'.

In this article, we discuss future workshops as a method in qualitative research on sensitive topics and silenced experiences, rather than taking an action research approach that treats such workshops as a means to share experiences for the purpose of enhancing collective actions or a management instrument. We explore these issues by looking at workshops conducted with children involved in divorce-related conflicts, and with young people about their experiences of social work, in order to deepen and nuance the discussion.

We begin with an introduction to future workshops as a method. We then present our experiences with conducting future workshops, including their potential and challenges, and we round off with a discussion about the viability of future workshops as a democratic and inclusive research method. We argue that the method is particularly well suited to studying children in conflictual or vulnerable positions and that these advantages could also be transferred to studies with other groups of people.

\section{The future workshop method}

The future workshop method was originally developed by Robert Jungk, Ruediger Lutz and Nobert R. Müllert in the 1970 s as a way to generate new ideas and solutions to social problems by gathering small groups of people to dream up and implement creative ideas and projects (see Jungk and Müllert, 1987). Over the years, the method has been used in a variety of areas including research, management and citizen involvement. Particularly in the field of action research, 'future workshops' have been adapted as a method to carry out participatory research aimed at bringing 
about social change (Andersen and Bilfeldt, 2015; Bladt and Aagaard 2013; Bodinet, 2016; Henning et al., 2009; Hitchcock and Wesner, 2011).

At the future workshop, participants go through three phases: the critique phase, the fantasy phase and the implementation phase. The three phases are designed to enable the participants to come up with ideas and solutions in relation to a specific challenge or topic. The aim of the critique phase is to identify real problems and frustrations rooted in people's lived experience, and to release energy for creative thinking in the ensuing fantasy phase. In the fantasy phase, the participants work on utopian ideas about the best possible way to solve these problems. Thus, in this phase, reality is suspended, which supports creative and imaginative thinking by making way for the participants' hopes and dreams. This is important in order to avoid resignation and pragmatic solutions which do not really solve the problems, but appear to be the best option from an everyday resignation adaptive perspective (Jungk, 1988; Negt and Kluge, 2016). Rather than starting with pragmatism, the point is to start with critique and creative utopian thinking, and only then to introduce pragmatic thinking, which is given a space in the third phase, implementation. Here, the participants work on their visionary, utopian ideas to explore and plan how to transform them partially or wholly into realisable changes (Jungk and Mullert, 1987; Author, 2016).

Moreover, the method is characterised by visuality, playfulness and multiple modes of communication, in order to avoid the common risk, in group work, of verbal argumentation dominating. Thus, both the critique phase and the fantasy phase start with a brainstorm in which critique and visions (wishes and dreams) are addressed through key words which are noted on 'wall papers' (paper flip charts hung on the walls so that everybody can see them); no argumentation is needed and no counter-argumentation is allowed. Often, these phases are 'prepared' first, though play or a game designed to stimulate an unrestrained atmosphere, playfulness, fantasy and creativity. After the brainstorm, the key words are grouped into themes, and the participants choose which aspects they find most important and engaging and want to develop further. Here, they can choose to work with and communicate their work in different ways, e.g. in the form of theatre, posters, text, pictures, etc.

In the following, we present and discuss our experiences from 'future workshops' with children.

\section{Presentation of the divorce workshops}

The divorce workshops, in which a total of thirteen children aged 7-17 participated, were carried out as part of a (larger) project on children involved in divorce cases ${ }^{1}$. The objective of the

\footnotetext{
${ }^{1}$ The future workshops are part of a research and development project entitled XXXXX. The development project involves an intervention in which 100 families follow a process in their parental responsibility case that differs from the regular process in court, notably in that it involves comprehensive psychological mediation. The research project revolves around children's experiences with divorce-related conflict, focusing particularly on the positioning of
} 
workshops was twofold. The first goal was to involve the children and give voice to their experiences very early on in the research process, to ensure that their perspectives shaped the future direction of the study. The second goal was to allow the children's experiences and perspectives to inform the development of new methods for taking children's best interests and perspectives seriously in solving divorce-related conflicts in the judicial system. In this way, the workshops served a double purpose: 1) they formed part of the research project, and 2) they formed part of a more practical developmental project. In both cases, the children's experiences and knowledge were the key components, in line with our ethical, democratic and epistemological goals.

The aim of the future workshops was to produce knowledge about children's experiences of being a child in a divorce-related conflict. We wanted to hear from the children themselves about what it was like being them and living their lives; and we also wanted to hear about their experiences of encountering the judicial system. Besides age differences, the children differed in regard to gender, ethnicity, social background etc.; however, they had in common that their parents were unable to reach an agreement on custody and/or residence. Thus, they had all experienced conflict in relation to the divorce, and the judicial system had been involved in settling their parents' disputes.

Jungk and Müllert (1987) suggest a preparatory phase in which decisions on the topic of the workshop as well as practical arrangements, are made by participants and facilitators together. In the divorce workshops, the overall topic of 'being a child in a divorce-related conflict', was, however, chosen by us, the researchers, and we also organised the practical arrangements such as snacks and soft drinks, and placing the chairs in a semi-circle. We also informed them about the topic, purpose and process of the workshop. We chose this procedure to comply with the purpose of the workshop, and to allow time to explore the children's experiences and perspectives.

We carried out 3-hour workshops with two groups of children. Participation was voluntary, and informed consent was obtained from parents as well as from the children themselves. The children were informed that they could withdraw their consent at any time they wished, and specifically that they were free to leave the workshop or tell us not to use their input. None availed themselves of this opportunity.

When the children arrived, they appeared excited, but at the same time shy and a little inhibited, perhaps because they felt nervous and uncertain about how the workshop would proceed. In order to break the ice and create a friendly and informal atmosphere, we started with a small game. The children and the facilitators all stood in a circle, and the facilitators took turns to

children, listening to and involving children. In addition to the workshops, the research project consists of observational studies and narrative interview with children and parents in 15 case families, as well as group interviews with professionals. 
say "everyone who has $\mathrm{X}$, switch places". The questions were a mix of general topics, for instance "everyone who has a pet, switch places", and topics that related to the subject of the workshop, for instance "everyone who has been to a child conversation in court, switch places". Besides contributing to creating a playful atmosphere, this game showed the participating children that they had living conditions and experiences in common, and thus created a sense of interconnectedness from the very beginning.

After this introduction, we went on to the critique phase in which we invited the children's contributions by asking them: "What is bad about your parents' divorce?" We emphasised that their critique could touch on anything relating to or caused by the divorce, including everyday life, school and friends, family life and the court. Two facilitators were present: one facilitated the conversation, and the other wrote the children's points on a flip chart and made an accompanying illustrative drawing. Every statement was recorded, even if the child showed, by laughing or in some other way, that he or she had just said something for fun. After a short break, we moved on to the fantasy phase which encouraged the children to put aside reality and brainstorm over 'The Perfect Divorce'. This lead to a myriad of perspectives, some of them were quite different or even opposing - and again everything was recorded. We then encouraged the children to do some creative work in smaller groups (or individually, accompanied by one of the researchers, if they preferred) about the 'perfect divorce'. We had prepared the facilities to enable drawing, collages, writing, interviewing and recordings of themselves or one another. The combination of talking and working creatively, and especially the fact that the children could choose different formats for expressing themselves, generated valuable dynamics. After the group work, the participants presented their creative work to each other. These presentations formed the basis of further exploration of 'the perfect divorce' from a child's perspective. One of the groups made a collage showing a young child with happy thoughts and memories of holidays and celebrations. There was clearly a humourous element in the collage, which brought a smile to all our faces. However, there was also a clear message about the importance of happy holidays and celebrations, and the risk that these would be endangered for children in conflict-ridden divorce families. Thus, humour and seriousness were linked; with humour clearing the way for seriousness and the other way around, with the critique enabling utopian thinking rooted in real problems.

In the third phase, the implementation phase, we tweaked the method a bit. Thus, instead of exploring and planning how to transform their utopian, visionary ideas partially or wholly into realisable changes, we asked the children to give the adults good advice, bearing their utopias in mind. We explained that 'adults' could be parents, lawyers, judges, psychologists, teachers or others. The children were eager to offer their advice, which resulted in a long list of innovative suggestions.

Our reconfiguration of this phase was pragmatic and driven by considerations about what we could require of children in a three-hour workshop, as well as by the research goal rather than the action goal - of the workshop. Thus, one could argue that our approach would also 
be suitable for democratic and inclusive research with adults where the intention is not to conduct action research, or where the participants have limited time to devote to the workshops.

\section{Gatekeeping}

Our initial contact with the children and their parents was mediated by the court, which contacted parents involved in closed parental responsibility cases and asked for permission to send information about the workshops to the children and their parents. Due to the nature of such cases, it was, however, difficult to obtain the parents' consent to this first step. Most of them argued that their children had already been exposed to enough divorce-related questioning, and with the court case finally closed they wanted to protect their children from the potential trauma of having to talk about the process once again. Another challenge was that both parents had to consent to their children's participation, which was complicated by the fact that they lived in separate households, presumably had different views about the court case and its outcome, and that their relationships were typically characterised by distrust and aggression. In some cases, the mere fact that one parent had given his/her consent caused the other parent to withdraw his/her consent or refrain from granting it. Altogether, this meant that most of the children were never informed about the project, or invited to participate in it, because their parents declined. There were also cases in which the court (the judges) deemed that either the parents or the children were too vulnerable even to be informed about the workshops. Thus, we encountered a considerable degree of adult gatekeeping, often legitimised as protection. However, the protection rationale can be questioned. First, one might question the notion that participating in such a workshop is an exclusively unpleasant task. That is certainly possible - but it might also be stimulating and empowering. Many of the children confirmed the latter when we asked them about their experience of participating after the workshop. Second, several childhood researchers have problematised adults' right to make such decisions on behalf of children, as this undermines children's right to participate and make decisions about participation (Hood et al., 1996). One strategy to handle this, according to Thomas and O'Kane (2000), could be to communicate as much as possible directly with the children, however this is often not even an option due to generational power relations that are seen as natural and reified in legislation and ethical approval procedures.

\section{Interest in participation}

As already indicated, we had chosen the subject of the workshop beforehand to reflect the aims of research, notably to provide insights that could potentially improve supervisory and legal practices pertaining to divorce cases in the courts. Most parents acknowledged this as meaningful and 
important, but still refused to allow their children to participate. How might we explain this? One reason could be that many parents in this situation are exhausted by the divorce and its accompanying conflict and have little energy left to engage - and let their children engage - in activities which they do not see as helpful to their case. Likewise, the children, if they are informed at all, probably neither have the energy nor the inclination to take part following a probably exhausting and frustrating process. This is compounded by logistical challenges caused by children having to split their time between their parents, which in turn depends on their parents making agreements and transportation arrangements. Altogether, and combined with the adult gatekeeping mentioned above, recruiting enough children for the workshop proved to be very challenging. However - quite surprisingly - parents' reluctance to allow their children to participate diminished when we offered to reward the children with a gift certificate for their participation. After this, more parents and children showed interest in attending our workshop.

As indicated above, these challenges can be explained in the light of the special circumstances of doing research with children in divorce cases. However, they raise a more general issue, which is simply a little more extreme in our study case: namely, that when future workshops are conducted with the primary aim of democratic, qualitative data production rather than changing the lives of the involved people, participation becomes a question of altruism. In that light, it is understandable that some people, especially those in a difficult situation facing multiple pressures, or if the subject of the workshop is sensitive, are reluctant to participate. Add to this that despite receiving information about the aim and process, it is hard to explain or predict what will actually happen during the workshop, for the researchers as well as the participants. Furthermore, we asked the participants to meet us at a given location (we could not offer to visit them, or to carry out the workshop virtually), and we needed them to spend more hours with us than are usually required for an interview, for instance. Thus, they may have concluded that the risks and stressors of participating were much higher than the gains. It does not really matter whether their expectations were confirmed or refuted - the fact remains that as researchers, we were asking a lot, and that it was us who needed their assistance and not the other way around. In this light, material recognition, in the form of a gift certificate, for instance, as well as very clear communication about our gratitude for their contributions and an explanation about why they were so important, would seem to be not only a reasonable pragmatic solution, but also essential to ethical research practice. It is the least we can do when we ask for so much, especially if we ask it of people with complicated lives or in underprivileged positions.

Other researchers have discussed the suitability of paying and compensating informants (Alderson and Morrow, 2011; Grady, 2001; Head, 2009). The point that we want to make here is that participation in very sensitive and demanding activities, such as the future workshop, might need to be rewarded for reasons of fairness and pragmatism. Such rewards are, however, not without dilemmas. They may lead to greater commitment, which can be positive, but also negative if participants become more reluctant to withdraw in case they are no longer 
comfortable with participating. In the workshops with the children, we strove to be very attentive to the children's wellbeing throughout the workshop, and to communicate the legitimacy of

withdrawing. Conversely, rewards might also create superficial engagement so that participants show up but don't really engage in the process. In our case, this remained a hypothetical risk which did not materialise. All the children showed high engagement. Payment might also compromise real voluntary participation, with possible negative consequences for those who really need the money. However, rather than being an argument against payment, we suggest that this calls for extra ethical awareness in order to avoid negative consequences for participants.

\section{Homogeneity or heterogeneity}

Originally, we wanted to do two age-based workshops: one with children aged 10 or less, and one with children aged 11 and over. Our intention was to limit the age range of the children, in part due to scholarly recommendations for group interviews with children (Greig et al., 2007), but also because the future workshop method has to be accommodated to the age and maturity of the participating children, as well as to possible power relations arising from age (differences). However, as already discussed, getting children to participate in the workshops proved to be difficult, in part due to parental gatekeeping and logistical challenges. Therefore, we decided to suspend the age criterion and instead carry out two workshops with children of mixed ages, despite some concerns about this.

It turned out that these concerns were unfounded. The fact that the participating children were far from being a homogeneous group, not only in regard to age, but also communicative competences and preferences, seemed to open up a productive space for exploring their shared and different experiences and perspectives, rather than creating distance and power imbalances. Thus, the older children cared for the younger ones, and thereby contributed to the friendly, relaxed and supportive atmosphere that we wanted to create, for example by explaining to the younger ones (or other children, who hadn't heard or understood something important) what we, the facilitators were trying to explain about the workshop process. Likewise, they asked in-depth questions and suggested interpretations of laconic statements that we found hard to understand. Thus, children who found it easier to express themselves verbally helped us and the other children to verbalise their experiences. Moreover, the less verbal (often younger) children mirrored themselves in the more articulate (often older) children's words, and found the inspiration and courage to express their points of view - even if these differed from what had just been said by someone else. Those differences also helped the children to reflect beyond their 'here and now' situation, and to remember how they had felt and thought about things before. So instead it just being us, the workshop facilitators (i.e. the researchers), who helped the children to express themselves, the mixed age group and differences in verbal 
communication skills proved to support the children's ability and inclination to share their experiences, feelings and views.

Beside age and language differences, the children also differed in regard to the stage of their parents' divorce. Thus, for some of the children, the divorce had occurred several years before the workshop, while for others it was quite recent. This diversity enabled us to capture children's reflections on what might be called the different stages of their parents' divorce. For instance, a child whose parents had divorced several years before said 'Oh, I remember right after my parents got divorced, everything was chaos' as a response to another child whose parents had divorced more recently. The sensation of chaos evoked here, although not explicitly mentioned by the child whose parent had recently divorced, helped to jolt the other child's memory, and enabled him/her to interpret and deepen the first child's story, as well as to verbalise the differences in their here-and-now experiences (chaos versus non-chaos) both in relation to the stage of the divorce process and also to the mechanisms/acts that supported a transition from chaos towards a new normality in their everyday lives.

Our experiences from these future workshops therefore challenge the common assumption that homogeneous groups are best, and invite reflections about which kind of tensions between homogeneity and heterogeneity are likely to be most productive when it comes to creating a safe and trusting space in which participants' voices and often ambiguous experiences can emerge - something that is essential for in-depth exploration of a phenomenon. Obviously, the participants must share some experience of the phenomenon being researched, but in regard to all other aspects differences may, in fact, be productive. Sometimes, however, the reverse is true, as one of the authors realised when carrying out a future workshop with a group of young people, about the merger of three social work programmes. The staff wanted to base the merger (a top-down decision triggered by economic cutbacks) on the needs and perspectives of three quite different groups of young people who were very frustrated about the merger and afraid to lose something that mattered a lot to them. Instead of directing their frustration towards those responsible for the decision, the young people projected it onto one another, something that became very clear in the critique phase of the future workshop. Here, the group's diversity created schisms that undermined the workshop facilitator and staff members' efforts to create a safe and trusting space. In this case, then, the group's heterogeneity proved to be counterproductive. The immediate, quite banal lesson from this is that while diversity can be very productive, oppositional positions and conflicts of interest between groups of participants are not. However, in some cases it might be difficult to identify possible oppositional positions and conflicts of interest beforehand, as many types of difference carry this risk. Attempts to eliminate this risk might, therefore, lead to too much homogeneity. Another strategy is to take the risk (while avoiding group constellations with known conflicts of interest) and prepare to handle possible oppositional positions by engaging more facilitators and arranging for extra rooms, making it possible to split the groups into separate workshops should the need arise. 


\section{Concluding discussion}

In this article, we presented future workshops with children as a qualitative research method, and discussed the potential, challenges and dilemmas involved in using this method to conduct democratic and inclusive research. Traditionally, future workshops have been associated with action research, but in this study we adapted the approach and used it as a non-action research method. We were particularly interested in the implications of this adaptation, not least because of the democratic and inclusive mechanisms of the classical future workshop: were we just conducting yet another kind of group interview, and if so was that a problem given that our goal was to carry out democratic, inclusive research?

Group interviews can enhance democratic and inclusive research, but they can also have the opposite effect. Some children (and adults) prefer being with peers - they feel more relaxed that way than in one-on-one situations with researchers whom they don't know, and this helps to modify the power relations between the (adult) researcher and the children, who may also be inspired by the other children. Conversely, group dynamics carry the risk that certain norms will prevail, restricting the space for expressing alternative perspectives. Furthermore, in group settings, shyness may prevent some participants from talking freely in the group, and some participants can be more trend-setting than others (Grieg et al., 2007). All that said, however, we consider that the future workshop design helps to minimise the risks and improve the benefits of this type of research. Crucial elements include the playful atmosphere and the rules (i.e. participants must be either critical or engage in utopian dreaming; and must brainstorm rather than argue and question), which serve to minimise arguments and to prevent domination by the most outspoken or articulate participants. We also found that the introductory game, which is not part of the classical future workshop, enhanced the children's recognition of common experiences and created an atmosphere characterised by solidarity and inclusiveness.

Having said that, we also recognise that our adaptation of the future workshop method limited its democratic and inclusive potential in other ways. Thus, the fact that we predefined the objectives for the workshops may be seen as undemocratic, and might have led to self-exclusion by some potential participants, which we experienced as lack of interest on their part. This may be one reason why it was so challenging to recruit children to take part in the workshops. Nevertheless, our version of the future workshop differed from the classical focus group interview in which the goal of the research is predefined and the facilitators steer how the subject is explored; in our workshops we did not predefine specific questions but merely formulated a topic for joint investigation. In addition, we were equally attentive to everything that happened, including humoristic statements, thus supporting the goal of the workshops to be a creative participatory process rather than merely a collection of opinions and data. 
Our adaptation of the final phase with the aim of collecting good advice from the participants (rather than them taking action to produce change as in the classical future workshop) also constitutes a radical transformation of the method so that it becomes more 'interview-like'. Thus, in some group interviews, the facilitators sum up by asking for advice. However, our future workshop advice phase differed in the sense that it was grounded in free-floating critique and utopian thinking rooted in everyday experiences, which released energy and enhanced radical and creative advice. This resonates with experiences from modified future workshops with children in residential care (Author, 2016).

The generation of new, innovative ideas is a key element in the future workshop method. By first allowing room for the participants' criticism and then encouraging them to dream freely with no strings attached, an inventive atmosphere is created. Furthermore, listening to the participants and paying attention to everything - even what is said in fun - creates a playful, nonthreatening kind of seriousness. These elements make the method particularly useful when studying sensitive subjects, such as children experiencing parental divorce. These children are often trapped in the middle of their parents' conflict and are adept at weighing their words very carefully in order to prevent hurting one or both parents or escalating the conflict.

Our experiences with the divorce workshops suggest that the future workshop method offers advantages, when adapted, when studying children in conflictual situations. These advantages could potentially be transferred to researching sensitive issues with children in general, and since the advantages described above are not linked to the participants' age, their transferability is arguably more generally applicable both to adults and children. Furthermore, despite the fact that the method is particularly useful for studying people in difficult situations or addressing sensitive issues, we argue that it can also be very fruitful when studying other topics or groups. Conflicts and sensitive issues can be understood broadly; indeed, a lot of qualitative research revolves around some sort of conflict or at least situations and topics that are not straightforward, and may thus be said to address sensitive issues.

As mentioned in the introduction, bringing about change has traditionally been a key aim of the classical future workshop. However, future workshops' (with children) as a research method are not necessarily aimed at change. It is therefore important to explain to the participants that the workshops will not necessarily have any immediate impact on their individual situation. Interestingly, however, in the case of the divorce-focused future workshops, the children's perspectives did, in fact, have a great impact both on the research project and the developmental project. They seem to have triggered changes in the way children are perceived in parental responsibility cases as well as in the way these cases are organised. Furthermore, some of the children reported that participating in the future workshop had contributed to their understanding and articulation of feelings and opinions. Similar empowering effects of this method are echoed in other projects (Author, 2017). Hence, participating may have enhanced their understanding of their own situation and by extension their ability to articulate their needs 
and perspectives. In this way, the workshops have arguably contributed to the empowerment of the participants - an objective that is very much in line with our democratic and inclusive research goals.

In this article, we reported how gatekeeping by the children's parents prevented some children from participating. However, gatekeeping in the form of intended or purported protection is related to power relations that are regarded as natural and reified in legislation and ethical approval procedures, and which reach beyond research with children, affecting various groups in vulnerable positions. Gatekeeping thus constitutes a critical issue in research that strives to be democratic and inclusive. These challenges can be handled through trust and cooperation with gatekeepers, combined with tangible compensation such as payment. However, critical scrutiny and discussion of legislation and ethical approval procedures remain essential: do they really serve people in vulnerable positions, or do they contribute to discrimination and exclusion from democratic participation?

The main objective of the divorce-related future workshops was to make room for the children's own experiences and voices. We wanted to create a free space in which the participants could come forward with whatever perspective or thoughts they had. However, when researchers interact closely with the field, as occurs during future workshops, it is also important to be aware of the researchers' position and the power relations connected to this. In our experience, some of the uneven power relations between adult researchers and participating children are evened out at future workshops. This is also likely to be true for the relationship between adult researchers and adult participants. However, the extent to which it is actually possible to level out power relations remains debatable. Thus, despite our goal to adopt a very open approach and create a free space for the participants, it is impossible to eliminate the risk that the researchers' perspectives (affect the topics discussed at the workshops. Furthermore, it is the researcher who analyses and communicates the results, giving him/her a crucial definitional power. This feeds into a general discussion on power relations in research, and calls for ethical awareness not only in the empirical phase, but also when analysing and communicating the results, not least when we aim and claim to be conducting democratic research.

\section{Funding}

Details withheld for peer review

\section{References}


Alderson, P. (2000) Children as Researchers. In Research with Children. Christensen, P. and James, A. (eds). Falmer Press: London: pp. 241-257.

Alderson, P \& Morrow, V. (2001)The Ethics of Research with Children and Young People. London: SAGE.

Andersen, J \& A. Bilfeldt (2015) Action research in nursing homes. Action Research 14 (1): 19-35.

Bladt, M. (2013) De Unges Stemme - udsyn fra en anden virkelighed. Roskilde: Roskilde Universitet. Institut for Samfund og Rumlig Forandring.

Bladt, M. og K. Aagard Nielsen (2013) Free space in the processes of action research. Action Research 11(4): 369-385.

Bodinent, J. C. (2016): Futures of Hope. The Importance of Positive Futures Images at the Community College Level. World Futures Review 8 (4): 172-179.

Brennalt, Y. et al. (2017): Details withheld for peer review

Brusselius-Jensen, M. (2014) What Would Be the Best School Meal If You Were to Decide? Pupils Perceptions on What Constitutes a Good School Meal. International Journal of Sociology of Agriculture \& Food 21 (3): 293-307.

Bruselius-Jensen, M. (2010). Poetiske perspektiver på det gode skolemåltid - børns muligheder som medskabere af skolens måltider. Roskilde: Roskilde Universitet. Institut for Psykologi og Uddannelsesforskning.

Børnerådet (2016) Håndbog i Børneinddraggelse. København: Børnerådet.

Børnerådet (2012) De prøver at gøre det så normalt som muligt. København: Børnerådet.

Chilisa, B (2012) Indigenous Research Methodologies. London: SAGE.

Christensen, P. and James, A. eds. (2000) Research with children: perspectives and practices. London: Falmer press.

Clark, A.: Breaking methodological boundaries? Exploring visual, participatory methods with adults and young children. European Early Childhood Education Research Journal 9 (3): 321-330

Clark, A. \& P. Moss (2011): Listening to Young Children: The Mosaic Approach, second edition. London: NCB.

Clausen, L. T. (2012): Unges bud på nationalparker i Danmark. In K. Buchieck (ed.) Kritiske Perspektiver på National-og Naturparker. Frydenlund Academic: 114-141. 
Clausen, L. T. \& C. Smith (2017): Det tegne- og fremtidsbaserede interview. In J. Kampmann et al. (eds.): Interview med børn. København: Hans Reitzels Forlag: 165-186.

Corsaro, W. (2005) The Sociology of Childhood. Indiana University, Bloomington: Pine Forge Press.

Crow, G (2012) 'Methodological Challenges for the 21st Century', presentation at the University of Sheffield. Available at: http://www.sheffield.ac.uk/polopoly fs/1.172803!/file/1120crow.pdf Google Scholar

Dewey, J. (1907): The School and Society. Chicago: University of Chicago Press.

Edwards, R and T. Brannelly (2017) Approaches to democratizing qualitative research methods. Qualitative Research 17(3): 271-277.

Fine, G. and Sandstrom, K. (1988) Knowing Children: Participant Observation with Minors. London: SAGE.

Fjordside, S. (2010) Rejsen til en bedre fremtid - en undersøgelse af grønlandske unges mulighed for medindflydelse. Integreret speciale i Socialvidenskab og Pædagogik \& Uddannelsesstudier. Roskilde: RUC

Fjordside, S., Lindberg, S., Schjellerup, H. \& Sommer, M. 2016 Unge, udenforskab og social forandring: nordiske perspektiver. Wulf-Andersen, T., Folles $\emptyset$, R. \& Olsen, T. (red.). Frederiksberg: Frydenlund Academic, 139-162.

Flyvbjerg, B. (2006): Five Misunderstandings About Case Study Research. Qualitative Inquiry 12 (2): 219-245 Foucault, M. (1981) The History of Sexuality, vol. 1, Harmondsworth: Penguin.

Grady, C. (2001) Money for Research Participation: Does It Jeopardize Informed Consent?, American Journal of Bioethics, 1:2, 40-44.

Greig, A, Taylor, J. \& MacKay,T. (2007) "Doing research with children". London: SAGE.

Groundwater-Smith, S., Dockett S. and Bottrell, D. (2015): Participatory research with children and young people. Sage Publications.

Grower, S. (2004) Why Won't They Listen to Us? On Giving Power and Voice to Children Participants in Social Research. Childhood 11(1): 81-93.

Hallet, C \& Prout, A. red. (2003) Hearing the voices of children: social policy for a new century. London: Routledge: Falmer.

Head. E. (2009) The ethics and implications of paying participants in qualitative research. International Journal of Social Research Methodology, 12:4, 335-344.

Henning, C. U. Åhnby \& S. Österström (2009): Senior Housing in Sweden: A New Concept for Aging in Place. Social work in public health 24(3): 235-254 in James, A., Jenks C. and Prout, A. (1998) Theorizing childhood. 
Hitchcock, M \& S Wesner (2011) The 'SHIP' Approach and its Value as a Community-based Research Method in Bali, Indonesia. Current Issues in Tourism 11(1): 84-100.

Holmstrøm, S., Gietz-Johansen, T. \& Kampmann, J. (2011) Pigeliv og Fælles Læreprocesser-aktionsforskning med minoritetspiger i et alment boligområde Roskilde: Roskilde Universitet, Institut for Psykologi og Uddannelsesforskning.

Hood, S., Kelley, P. and Mayall, B. (1996) Children as research subjects: a risky enterprise, Children andSociety, 10(2), pp. 117-28.

James, A. (1998) 'Researching children's social competence: methods and models', in Woodhead, M., Faulkner, D. and Littleton, K., Making Sense of Social Development, London: Routledge.

James, A., Jenks, A. and Prout, A. (1998) Theorizing Childhood. Cambridge: Polity Press.

Jungk, R. (1988): Modets princip. København: Politisk Revy.

Jungk, R and Müllert, N. (1987) Future Workshops - How to Create Desirable Futures. London: Institute for Social Invention.

Levinas, E. (1969): Totality and Infinity. Duqusne: University Press.

Lyon, D. and Carabelli, G. (2015) Researching young people's orientations to the future: the methodological challenges of using arts practice. Qualitative Research Onlinefirst

Mandell, N. (1991) The least-adult role in studying children, in Waksler, F. C. (ed.), Studying the Social Worlds of Children: Sociological Readings. London: Falmer.

Negt, O. \& A. Kluge (2016/1972): Public Sphere and Experience. Toward an Analysis of the Bourgeois and Proletarian Public Sphere. London \& New York: Vergo.

Nielsen, K. A. (1992): Forskning i nye flexible produktionsmetoder: Forskerroller og metodetilgange". Dansk Sociologi 3 (4): 24-44.

Nind, M. (2017): The practical wisdom of inclusive research. Qualitative Research 17(3): 278-288.

Petersen, T. (2006): “Development of a city logistics concept". Production Planning \& Control. The Management of Operations 17(6): 616-623.

Percy-Smith, B. and Thomas, N. eds. (2010) Handbook of Children and Young People's Participation: Perspectives from Theory and Practice. Abingdon: Routledge.

Punch, S. (2002): Research with children: The same or different as research with adults?. Childhood 9(3): 321-341.

Qvortrup, J. (1994): Childhood Matters. In Qvortrup et al. eds. Childhood Matters. Social Theory, Practice and Politics. Brookfield VT: Avebury: 1-23. 
Raithelhuber, E. (2016): Extending agency: the merit of relational approaches for Childhood Studies. Esser et al. (eds.): Reconceptualising Agency and Childhood. Routledge.

Rasmussen, K. (2014) Børns utopier. Psyke \& Logos. Vol.35: pp 212-228.

Thomas, N \& C. O'Kane, (2000) Discovering what children think: Connections between research and practice. British Jounal of Social Work. Vol 30 (6): pp 819-835.

Uprichard, E. (2010): Questioning research with children: Discrepancy between theory and practice? Children and Society 24(1): 3-13.

Wall, J. (2013) Childism: The Challenge of Childhood to Ethics and the Humanities. In Duane, (ed.) The Children's Table: Childhood Studies and the New Humanities. Athens, GA: University of Georgia Press: 6884.

Wall, J. (2014): Democratizing Democracy: The Road from Women's to Children's Suffrage. International Journal of Human Rights, Special Issue, edited by Grover, S. (2014) 18 (6): 646-659.

Wihstutz, A. (2017): From Objects of Care to Citizens - Young Carers' Citizenship. Warming \& Fahnøe (eds): Lived Citizenship on the Edge of Society. Rights, Belonging, Intimate Life and Spatiality. Palgrave Politics of Identity and Citizenship Series: 175-199.

Åkerström, J. and Brunnberg, E. (2012) Young people as partners in research: experiences from an interactive research circle with adolescent girls. Qualitative Research 13(5) 528-545: SAGE.

Author (2006), details withheld for peer review.

Author (2011), details withheld for peer review.

Author (2016), details withheld for peer review.

Author (2018), details withheld for peer review. 